\title{
Global Trends in
}

\section{Large-Value Payments}

- The evolving landscape in which large-value payments systems (LVPSs) operate is having important effects on the financial system.

- An analysis of the current interbank payment environment points to three forces that are shaping ten trends common to LVPSs around the world.

- Technological innovation is making LVPSs safer and more efficient while allowing for new systems that are not limited to one country or currency.

- Structural changes in banking-such as immense growth in the financial sector, changes in the role of firms and their products, and greater globalization of financial institutions and their services - are influencing the use of LVPSs.

- The evolution of central bank policies is resulting in central banks becoming more active in monitoring existing and planned systems, assessing systems according to international standards, and inducing change.

Morten L. Bech is a senior economist at the Federal Reserve Bank of New York; Christine Preisig is a former senior policy expert at the Bank; Kimmo Soramäki is a Ph.D. candidate at Helsinki University of Technology on leave from the European Central Bank. This article was written while Mr. Soramäki was on leave from the European Central Bank and acting as a research consultant to the Federal Reserve Bank of New York.

Correspondence: <morten.bech@ny.frb.org>

\section{InTRODUCTION}

Clobalization and technological innovation are two of the

$\checkmark$ most pervasive forces affecting the financial system and its infrastructure. Perhaps nowhere are these trends more apparent than in the internationalization and automation of payments. The evolving landscape is most obvious in retail payments. The use of paper checks is in rapid decline or has been eliminated in most of the industrialized world. Credit and debit cards can be used in the most surprising places. Internet banking with money transfer capabilities is common, and several providers are competing to service consumers' payments over the Internet and mobile devices.

In wholesale, or interbank, payments, the effect of globalization and technological innovation is probably less obvious to the casual observer-but it has been equally impressive. Given the importance of payments and settlement systems to the smooth operation as well as resiliency of the financial system, stakeholders need to understand and assess the potential consequences of this evolution. This article offers an in-depth look at the current environment for large-value payments systems (LVPSs). We describe ten trends common to LVPSs around the world and identify the key drivers of these developments and the most important policy issues facing central banks (see box). Furthermore, we provide empirical support for each of the trends by using numerous publicly available sources, including Bank for International Settlements

The views expressed are those of the authors and do not necessarily reflect the position of the European Central Bank, the Federal Reserve Bank of New York, or the Federal Reserve System. Any errors or omissions are the responsibility of the authors. 
Ten Global Trends in Large-Value Payments and Their Key Drivers

\begin{tabular}{|c|c|}
\hline \multirow{3}{*}{$\begin{array}{l}\text { 1. Technologice } \\
\text { Innovation }\end{array}$} & $\begin{array}{l}\text { 1. Diffusion of Real-Time Gross } \\
\text { Settlement Systems }\end{array}$ \\
\hline & 2. Take-off of Hybrid Systems \\
\hline & $\begin{array}{l}\text { 3. Emergence of Cross-Border } \\
\text { and Offshore Systems }\end{array}$ \\
\hline \multirow{2}{*}{$\begin{array}{l}\text { 2. Structural } \\
\text { Changes in } \\
\text { Banking }\end{array}$} & $\begin{array}{l}\text { 4. The Rise of Continuous Linked } \\
\text { Settlement Bank }\end{array}$ \\
\hline & $\begin{array}{l}\text { 5. Increasing Settlement Values } \\
\text { and Volumes }\end{array}$ \\
\hline \multirow{5}{*}{$\begin{array}{l}\text { 3. Evolution of } \\
\text { Central Bank } \\
\text { Policies }\end{array}$} & 6. Shrinking Average Payment Sizes \\
\hline & 7. Falling Numbers of System Participants \\
\hline & 8. Extended Operating Hours \\
\hline & 9. Declining Transaction Fees \\
\hline & $\begin{array}{l}\text { 10. Adoption of Common Standards } \\
\text { for Large-Value Payments Systems }\end{array}$ \\
\hline
\end{tabular}

(BIS) statistics on payments and settlement systems in selected countries (the "Red Book"). We focus on large-value payments systems in countries where the central bank is a member of the Committee on Payment and Settlement Systems (CPSS), a body under the auspices of the BIS (Appendix A).

Technological innovation, structural changes in banking, and the evolution of central bank policies are the three main reasons for the recent developments in large-value payments. First, technological innovation has created opportunities to make existing large-value payments systems safer and more efficient. Such innovation has also accommodated the industry's growing need for new types of systems that are not limited to a single country or a currency. Second, the financial sector has experienced immense growth over the last few decades accompanied by changes in the role of individual firms and the products they offer. In addition, financial institutions and their services have become increasingly globalized. These structural changes have affected how participants use largevalue payments systems. Third, the role of central banks in large-value payments systems has changed significantly in recent years. Central banks have become more involved in payments systems and have created formal and systematic oversight functions. The main focus lies in promoting safety and efficiency in LVPSs and in maintaining overall financial stability. Central banks therefore have taken more active roles in monitoring existing and planned systems, in assessing systems according to international standards, and, if necessary, in inducing change.
As the box illustrates, the ten trends that we describe can be assigned to three key drivers. The first four trends-the diffusion of real-time gross settlement (RTGS) systems, the take-off of hybrid systems, the emergence of cross-border and offshore systems, and the rise of Continuous Linked Settlement (CLS) Bank-are all associated with settlement technology and fall into the first category. Technological innovation has enabled new settlement methodologies to emerge that allow a better balance between settlement risks, immediacy, and liquidity requirements. RTGS systems have to a large extent replaced deferred net settlement (DNS) systems. However, the high liquidity needs associated with RTGS have led some system operators to explore liquidity-saving mechanisms and have motivated them to develop hybrid systems. Developments in payments system technology have also facilitated the emergence of systems that settle payments across national borders in one or more currencies. In addition, the clearing of payments is in some instances moving offshore and the ability of participants to connect remotely-eliminating the need for a physical "footprint" in the jurisdiction of LVPSs-is becoming more widespread. Foreign exchange (FX) settlement and counterparty risk are being managed more tightly in part because of the use of payment-versus-payment ( $\mathrm{PvP})$

\section{Technological innovation, structural changes in banking, and the evolution of central bank policies are the three main reasons for the recent developments} in large-value payments.

mechanisms. ${ }^{1}$ CLS Bank operates a multicurrency payments system for the simultaneous settlement of both sides of a foreign exchange transaction on a PvP basis. With CLS Bank, existing risks associated with FX trades are virtually eliminated.

The next three trends-increasing settlement values and volumes, shrinking average payment sizes, and falling numbers of system participants-as well as the emergence of crossborder and offshore systems (Trend 3) fall into the second category. They are determined largely by how the banking sector uses payments systems and by the structural changes taking place therein. The values and volumes originated over LVPSs grew exponentially until the turn of the century. However, in terms of value, growth has since slowed and is no longer outpacing economic growth as measured by GDP.

${ }^{1} \mathrm{PvP}$ ensures that a final transfer of one currency occurs only if a final transfer of the other currency or currencies takes place (Bank for International Settlements 2003). 
Because many LVPSs process a large amount of relatively low-value payments, the average payment size settled has shrunk. Hence, the dichotomy between small- and large-value payments systems is not always applicable. In addition, consolidation in the banking sector has led to fewer participants in LVPSs. Structural changes have also resulted in the emergence of global banks that require a global payment infrastructure, which in turn has led to the creation of new systems that accommodate these needs.

The last three trends and the rise of CLS Bank (Trend 4) fall into the third category. They are associated with central banks' operating policies regarding LVPSs. The service level of all systems is improving with longer operating hours. Some systems are even approaching a twenty-four-hour settlement cycle. Transaction costs in various LVPSs have been falling since the late 1990s because the savings achieved through improvements in operating efficiency have been passed on to system participants in the form of lower fees. Through the adoption of common standards, such as the CPSS' Core Principles for Systemically Important Payments Systems, risk management in LVPSs has become more standardized. Furthermore, the central bank community was the driving force behind the development of CLS Bank.

We now describe each trend in detail and conclude by commenting on the possible future of the large-value payments landscape.

\section{Trend 1: Diffusion of Real-Time Gross Settlement Systems ${ }^{2}$}

As a consequence of the rapid increase in values settled in largevalue payments systems in the 1980s, central banks became concerned about settlement risks inherent in the thenprevalent deferred net settlement systems. ${ }^{3}$ In particular, the banks were concerned about the potential for contagion (or even a systemic event) attributable to the unwinding of the net positions that would result if a participant failed to make good on its obligations when due. ${ }^{4}$

\footnotetext{
${ }^{2}$ For more on these systems, see Bech (2007) and Bech and Hobijn (2007).

${ }^{3}$ A DNS system effects the settlement of obligations or transfers between or among counterparties on a net basis at some later time (Bank for Internationa Settlements 2003)

${ }^{4}$ Unwinding is a procedure followed in certain clearing and settlement systems in which transfers of securities and funds are settled on a net basis, at the end of the processing cycle, with all transfers provisional until all participants have discharged their settlement obligations. If a participant fails to settle, some or all of the provisional transfers involving that participant are deleted from the system and the settlement obligations from the remaining transfers are then recalculated. Such a procedure has the effect of allocating liquidity pressures and losses attributable to the failure to settle to the counterparties of the participant that fails to settle (Bank for International Settlements 2003).
}

Over the last few decades, many countries have chosen to modify the settlement procedure employed by their interbank payments system with a view to reducing settlement risks and the potential for adverse systemwide implications. Most central banks have opted for the implementation of an RTGS system. Such a system reduces settlement risk, as payments are settled individually and irrevocably on a gross basis in real time, ensuring immediate finality. RTGS can also help reduce settlement risk by facilitating payment versus payment and delivery versus payment in the settlement of FX and securities transactions, respectively.

Fedwire is the world's oldest RTGS system. Its origins can be traced to 1918, when the Federal Reserve inaugurated a network of wire communications among the individual

Over the last few decades, many countries have chosen to modify the settlement procedure employed by their interbank payments system with a view to reducing settlement risks and the potential for adverse systemwide implications. Most central banks have opted for the implementation of an RTGS [real-time gross settlement] system.

Reserve Banks. In the early 1970s, the Fedwire system migrated to a fully computerized platform, and settlement in "real time" was achieved.

A number of western European countries began implementing RTGS systems in the 1980s. By 1988, RTGS systems operated in four of the six major currencies. RTGS adoption continued at a rate of roughly one country per year during the early 1990s. In 1992, the Treaty of Maastricht created the foundation for the Economic and Monetary Union (EMU). A year later, the central banks in the European Union (EU) agreed that each member state should have an RTGS system. Furthermore, in 1995 it was decided to interlink the national RTGS systems through the Trans-European Automated Real-time Gross settlement Express Transfer (TARGET) system to facilitate the European Central Bank's (ECB) single monetary policy and to promote sound and efficient payment mechanisms in euros. This decision led to a flurry of new systems and upgrades to existing ones. TARGET went live on January 4, 1999, and even EU countries that did not join the EMU at the outset (the United Kingdom, Denmark, and Sweden) were allowed to participate in the 
system. As the ECB made RTGS a prerequisite for membership in the EMU, prospective members in the rest of Europe began to implement RTGS. Furthermore, as hostilities ended in the Balkans in the late 1990s, governments began to rebuild their respective economies. They considered the establishment of sound and efficient financial systems a priority. RTGS systems were implemented with support from the EU, the International Monetary Fund (IMF), and the World Bank. With ongoing projects in Russia and Cyprus, the diffusion of RTGS in Europe is nearly completed.

Outside Europe, the rate of RTGS adoption since the mid1990s has been equally impressive. Australia and New Zealand implemented RTGS in 1998. In Asia, the rate of implementation has been fairly steady; on average, about one country per year has adopted RTGS. Six countries in the Middle East have done likewise. In Africa, the South African Reserve Bank (SARB) spearheaded RTGS adoption in 1998. Through the South African Development Community (SADC), ${ }^{5}$ SARB has participated in developing and strengthening the financial infrastructure in the rest of southern Africa. As of 2006, eleven African central banks have implemented RTGS, many with the support of the World Bank.

In the Western Hemisphere, Canada is the only Group of Ten (G-10) country that has decided not to implement an RTGS system. Instead, Canada opted for a hybrid system. ${ }^{6}$

Uruguay was the first country in South America to adopt RTGS in 1995. By 2006, seven of thirteen South American countries had followed suit. Implementation in Central America and the Caribbean has started only recently, but the Inter-American Development Bank is assisting RTGS efforts in the region.

The global diffusion of RTGS systems since the mid-1980s is evident from Exhibit 1. By 1985, three central banksthe Federal Reserve, Danmarks Nationalbank, and the Netherlandsche Bank_-had implemented RTGS systems. A decade later, that number had increased to sixteen, but RTGS was still utilized predominantly by industrialized countries. In recent years, however, transitional as well as developing countries have begun investing heavily in improving their financial systems, and now RTGS is a common choice for interbank payments. At the end of 2006, 93 of the world's

\footnotetext{
${ }^{5}$ The member states of the SADC are Angola, Botswana, Democratic Republic of Congo, Lesotho, Malawi, Mauritius, Mozambique, Namibia, Seychelles, South Africa, Swaziland, Tanzania, Zambia. and Zimbabwe.

${ }^{6}$ The Canadian Large-Value Transfer System (LVTS) processes payments with finality in real time, while settlement occurs on a multilateral net basis at the end of the day. Immediate intraday finality is achieved because settlement is guaranteed under all circumstances. This is facilitated by the use of collateral to secure participants' intraday net debit (negative) positions and by a residual guarantee provided by the Bank of Canada (see Arjani and McVanel [2006]). LVTS is considered equivalent to RTGS in terms of finality, as the Bank of Canada provides an explicit guarantee of settlement in case of participant failure.
}

174 central banks were using RTGS systems. The RTGS adoption rate was about one central bank per year in the latter part of the 1980s and the beginning of the 1990s. In the mid-1990s, the rate accelerated with the addition of three central banks in 1995 and five in 1996. Since then, the annual adoption rate has not dipped below three new central banks. It peaked in 2002, when a total of fifteen central banks implemented new RTGS systems.

\section{Trend 2: Take-off of Hybrid SysteMs}

As payments are settled individually in an RTGS system, sufficient liquidity needs to be available to fund each payment. Real-time gross settlement thus reduces settlement risks but results in an increased need for intraday liquidity to smooth nonsynchronized payment flows.?

Initially, central banks provided intraday credit free to commercial banks. This policy is no longer considered a viable option by the banks, as it exposes them (and ultimately

To reduce the need for intraday liquidity, several systems have developed different types of queue management and liquidity-saving features.

taxpayers), as guarantor of the finality of payments, to credit risk (see, for example, Humphrey [1986] and Bech and Soramäki [2005]). Thus, intraday liquidity is costly for participants either in the form of explicit fees or implicitly as the opportunity cost of collateral that participants need to pledge for an intraday credit line from the central bank. To reduce the need for intraday liquidity, several systems have developed different types of queue management and liquiditysaving features. The queue management features include different priority categories for payments and the possibility of reordering payments once in the queue. The liquidity-saving

${ }^{7}$ Payments systems can operate at different levels of liquidity requirements, delays, and risks. Depending on the system design, these can be traded off against each other. Liquidity requirements are highest when payments are settled continuously against full cover (as in RTGS). Liquidity requirements in an RTGS system can be reduced by delaying payments until incoming payments allow settlement. In deferred net settlement systems, payments are settled only periodically by transferring only net amounts, thus payments are delayed from time of receipt until time of settlement. In such systems, banks can reduce delays by crediting customer accounts before final settlement. This will, however, come at the expense of credit risks, as final settlement may not take place as expected. For an in-depth discussion of these trade-offs, see Leinonen and Soramäki (1999). 
ExhIBIT 1

Diffusion of Real-Time Gross Settlement Systems Worldwide
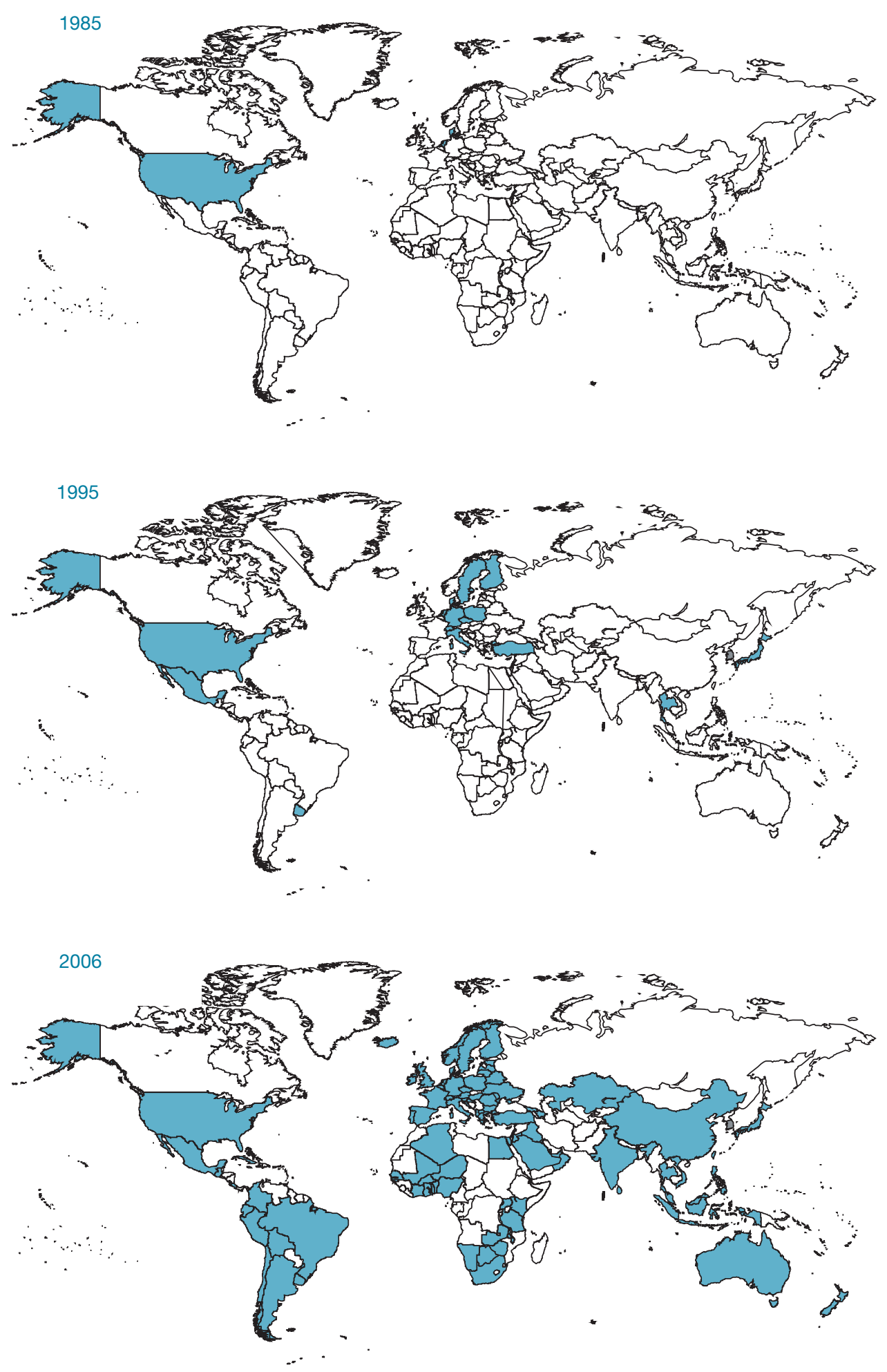
Chart 1

Payments Settled in RTGS, DNS, and Hybrid Modes, 1999 and 2005

U.S. Dollar Equivalent
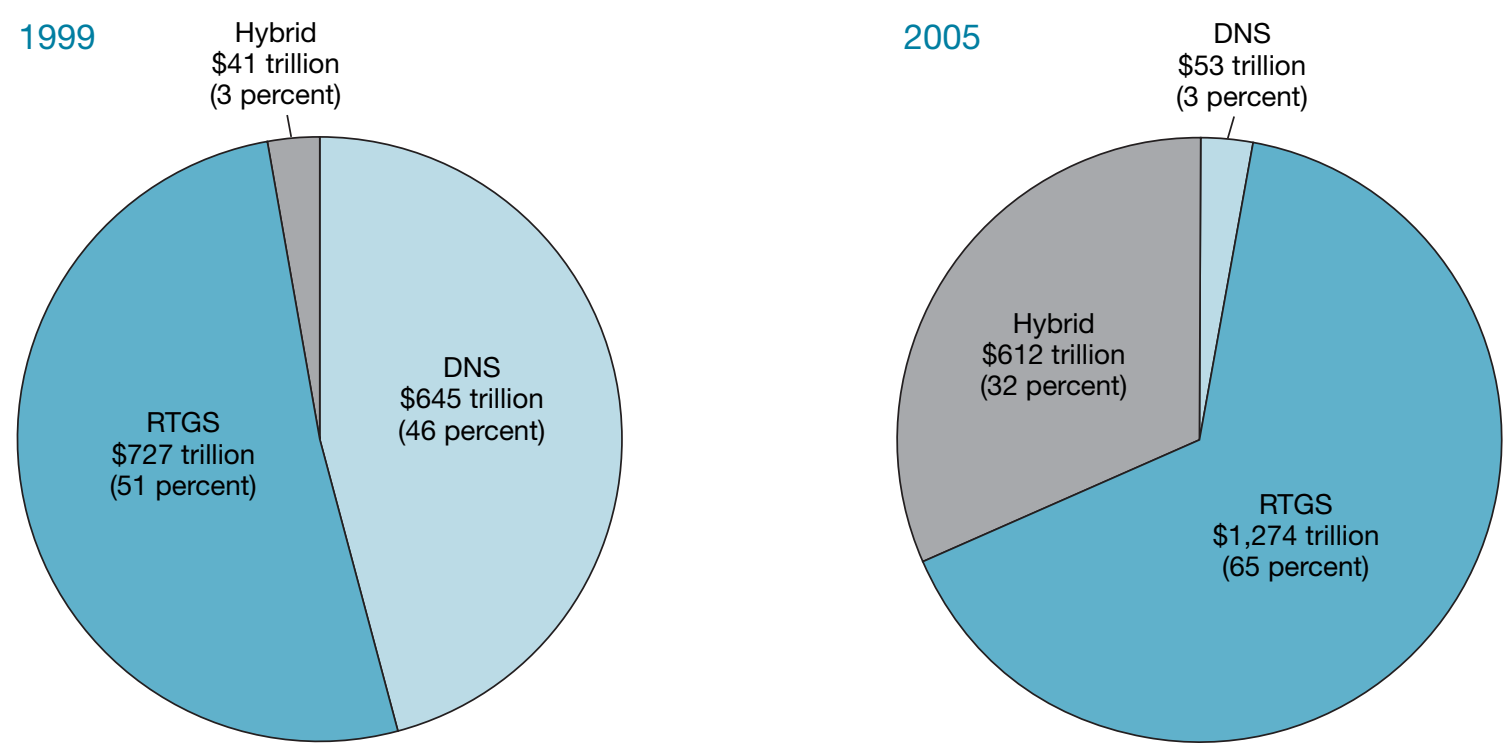

Sources: Bank for International Settlements; authors' calculations.

Notes: RTGS is real-time gross settlement; DNS is deferred net settlement. Figures represent Fedwire, CHIPS, CHAPS, SIC, TARGET, MEPS, K-RIX, LVTS, PNS, Euro1, and HKD CHATS. DNS in 1999: Euro1 and BoJ-NET. Hybrids in 2005: PNS, LVTS, CHIPS, and RTGSplus. Systems are described in Appendix A. The value for RTGSplus was subtracted from the value for TARGET in computing the value settled via RTGS.

features typically involve the netting of payments in the queue, a feature commonly referred to as gridlock resolution (see Bech and Soramäki [2001]). ${ }^{8}$

Another approach to balancing risks, payment delays, and liquidity needs more efficiently has been the development of hybrid systems (see McAndrews and Trundle [2001] and Leinonen and Soramäki [1999]). Hybrid systems employ advanced settlement algorithms that combine components of both net and real-time gross settlement. Some payments may be settled individually, as in RTGS, while others, usually less urgent payments, may be pooled together and netted. ${ }^{9}$ Other features may include bilateral limits to manage credit exposures and reciprocity. The distinction between RTGS systems and hybrid systems can be fluid. In this article, hybrid systems are defined as systems with either separate payment streams for urgent or nonurgent payments and/or systems that

${ }^{8}$ Gridlock is a situation that can arise in a funds or securities transfer system when the failure of certain transfer instructions to be executed (because the needed funds or securities balances are unavailable) prevents the execution of a substantial number of instructions from other participants (Bank for International Settlements 2003).

${ }^{9}$ For example, the RTGS share of the German hybrid system RTGSplus is about 10 percent, whereas the netted payments share is 90 percent. employ advanced bilateral or multilateral offsetting algorithms on a continuous basis. Prominent examples of hybrid systems include RTGSplus in Germany, LVTS in Canada, CHIPS in the United States, and Paris Net Settlement (PNS) in France.

With regard to settlement method, the major development in payments systems in CPSS countries has been the sharp increase in value settled by hybrid systems (Chart 1). In 1999, 3 percent of payment value was settled by these systems. RTGS settlement accounted for approximately 50 percent of payments and DNS settlement for roughly 45 percent. $^{10}$ By 2005, hybrid systems accounted for close to one-third of value settled, whereas RTGS increased to almost two-thirds. The only remaining DNS system, EURO1, accounted for less than 3 percent of total value settled in CPSS large-value payments systems.

${ }^{10}$ Prior to 2001, BoJ-NET provided both DNS and RTGS settlement modes. However, the RTGS settlement mode was seldom used by banks because of its higher liquidity costs. In 2001, the Bank of Japan introduced a reconfigured BoJ-NET and abolished DNS. Just before the change, only 3 percent of Japan's wholesale payments were settled via RTGS (Selgin 2004). 


\section{Trend 3: Emergence of Cross-Border and OfFshore Payments Systems}

Large-value payments systems have traditionally settled payments in the local currency among participants located within the same national borders as the system. However, since the late 1990s, systems have emerged that allow payments to settle across national borders, facilitate settlement in multiple currencies, and permit participants to be located in a foreign jurisdiction. The two key drivers of the development of crossborder and offshore systems have been the introduction of the euro and the demand for payment settlement in foreign currencies as part of payment-versus-payment FX transactions, particularly in the Asian time zones.

To analyze these new types of systems, we classify them according to the location of their participants and the currencies in which they settle payments. A simple taxonomy is presented in Table 1. The type of participants and currencies that a system services are each divided into three groups. Participants are categorized as domestic, remote, or cross-border, whereas the currencies settled are classified as local, foreign, or multiple.

We refer to participants located in the same country as the system as domestic participants. A remote participant has neither its head office nor any of its branches located in the country where the transfer system is based (Bank for International Settlements 2003). Cross-border participants are payees and payers located in different countries. The groups are not exclusive, as systems with remote or cross-border participants also service domestic participants. Further on, we distinguish between systems that settle in the local currency of the country where the system is located, systems that settle in a single foreign currency, and systems that settle in a set of multiple currencies that typically includes the local currency.

TABLE 1

Taxonomy of Payments Systems

\begin{tabular}{lccc} 
& \multicolumn{3}{c}{ Settlement Currency } \\
\cline { 2 - 4 } Participant Type & Local & Foreign & $\begin{array}{c}\text { Multiple (PvP in } \\
\text { Foreign Exchange } \\
\text { Settlement) }\end{array}$ \\
\hline Domestic & $\begin{array}{c}\text { Fedwire, CHIPS, } \\
\text { CHAPS Sterling, }\end{array}$ & $\begin{array}{c}\text { USD CHATS, } \\
\text { LVTS, RIX, PNS, } \\
\text { BoJ-NET }\end{array}$ & $\begin{array}{c}\text { HKD, USD, } \\
\text { and EUR } \\
\text { CHATS (PvP } \\
\text { arrangement } \\
\text { in CHATS) }\end{array}$ \\
Remote & SIC & Euro-SIC & - \\
Cross-border & $\begin{array}{c}\text { TARGET, } \\
\text { EURO1 }\end{array}$ & CHAPS Euro & $\begin{array}{c}\text { CLS Bank, } \\
\text { RENTAS-CHATS } \\
\text { link }\end{array}$
\end{tabular}

Notes: Systems are described in Appendix A. PvP is payment-versuspayment.
Fedwire and CHIPS in the United States, CHAPS in the United Kingdom, and BoJ-NET in Japan, to name a few, are traditional large-value payments systems that settle payments in the local currency for domestic participants.

Originally, participation in the Swiss Interbank Clearing (SIC) system was limited to banks domiciled in Switzerland and the Principality of Liechtenstein. However, since 1998 remote access to SIC has been granted to banks domiciled outside Switzerland. Any bank worldwide can participate in SIC as long as it meets the admission criteria (see Heller, Nellen, and Sturm [2000]). Among other things, remote access has allowed foreign banks that participate in the futures and

\section{The two key drivers of the development of cross-border and offshore systems have been the introduction of the euro and the demand for payment settlement in foreign currencies as part of payment-versus- payment FX transactions, particularly in the Asian time zones.}

options exchange EUREX to process Swiss franc transactions directly via SIC without having a physical "footprint" in Switzerland. At the end of 2006, of the 331 SIC participants, 72 were so-called remote members.

In 1999, with the introduction of the euro, two panEuropean interbank payments systems were introduced. TARGET and EURO1 both settle cross-border payments in euros. Currently, TARGET consists of 17 RTGS systems with 1,058 direct participants ${ }^{11}$ (see Appendix B for more on TARGET and its individual components). In 2006, TARGET processed on average 326,000 daily payments worth about 2.1 trillion euros (see Appendix C for more on cross-border payments within TARGET).

In conjunction with EU central banks' efforts, the European Banking Association (EBA) established, much like CHIPS, a private sector complement to TARGET: the EURO1 system. Today, the system has 70 participating banks and processes on average 185,000 payments a day with a total value of around 195 billion euros. TARGET and EURO1 are examples of LVPSs that settle cross-border payments in a local currency.

${ }^{11}$ The systems are Belgium ELLIPS (Belgium), KRONOS (Denmark), RTGSplus (Germany), HERMES (Greece), SLBE (Spain), EP RTGS (Estonia), TBF (France), IRIS (Ireland), New BIREL (Italy), LIPS-Gross (Luxembourg), TOP (the Netherlands), Artis (Austria), SORBNET-EURO (Poland), SPGT (Portugal), Payments System (Slovenia), BoF-RTGS (Finland), and CHAPS (United Kingdom). 
The United Kingdom, Sweden, and Denmark did not join the EMU at the outset. However, in expectation that these countries would eventually join, separate euro RTGS systems were built and connected to TARGET: CHAPS Euro in the United Kingdom, E-RIX in Sweden, and DEBES in Denmark. From the perspective of the Table 1 taxonomy, these systems can be thought of as facilitating cross-border payments in a foreign currency. However, with the advent of the next generation of the TARGET system, the euro functionality of all three systems will be phased out. E-RIX already closed at the end of 2006.

Another implication of the common currency was the introduction of euroSIC in 1999. The system allows Swiss banks to conduct euro transactions. It operates on the same platform as the Swiss franc system, but settlement takes place on the books of the Swiss Euro Clearing Bank (SECB) in Frankfurt, Germany. SECB provides a link to the euro area by being a direct participant in RTGSplus, through which access to TARGET is established. ${ }^{12}$ In addition, remote access is possible in euroSIC. Within the taxonomy, euroSIC is a system that settles a foreign currency for domestic and remote participants.

CLS Bank operates a system that settles multiple currencies for participants located in different countries (we discuss it in more detail as part of Trend 4). A similar system is the link between the ringgit real-time gross settlement system in Malaysia (the RENTAS system) and the U.S. dollar real-time gross settlement system in Hong Kong (USD CHATS). The link, established by the Hong Kong Monetary Authority and Bank Negara Malaysia in 2006, allows for PvP foreign exchange settlement of USD-MYR trades. In the Table 1 taxonomy, the link can be considered a cross-border PvP system.

Since 2000, several new systems that settle a foreign currency for participants located within the same national borders as the system itself have emerged:

- In 2000, Hong Kong Interbank Clearing Ltd. (HKICL) introduced the U.S. Dollar Clearing House Automated Transfer System (USD CHATS) to clear USD payments in the Asian time zone. The system is technically the same as the Hong Kong dollar CHATS system, except that settlement currently takes place on the books of a private bank (HSBC) in New York City.

- In April 2002, the Brazilian Bolsa de Mercadorias \& Futuros (BM\&F) FX Clearinghouse initiated operations for settling USD-BRL trades. The Clearinghouse maintains a settlement account in the local currency with the Central Bank of Brazil and settlement accounts

\footnotetext{
${ }^{12}$ Interestingly, the largest Swiss bank, UBS AG, processes its cross-border euro payments via proprietary access to RTGSplus and not via euroSIC (see the interview with Stephan Zimmerman, Head of Operations at UBS AG, at $<$ http://www.sic.ch/dl_tkicch_clearit14interview.pdf $>$ ).
}

CHART 2

Annual Value Settled by U.S. Dollar

Offshore Systems, 1999-2006

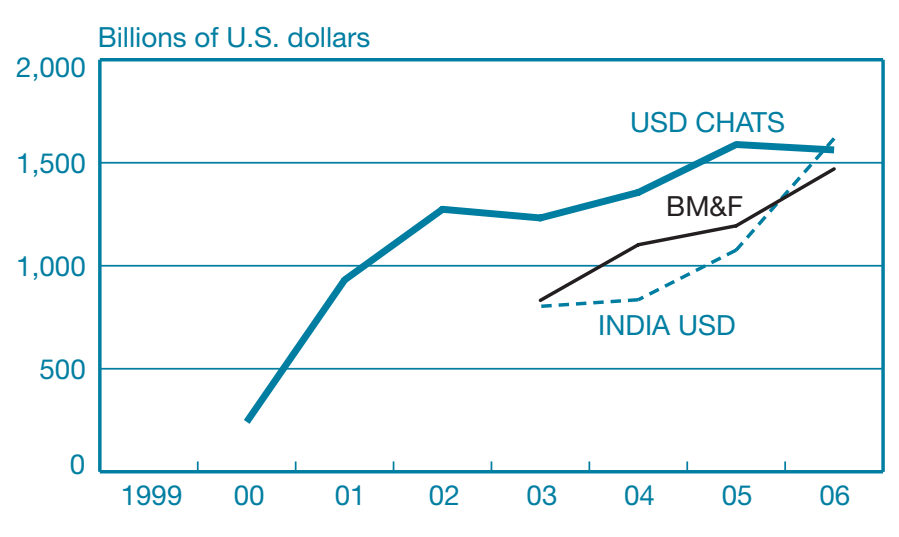

Sources: Hong Kong Monetary Authority; Clearing Corporation of India, Limited; Bolsa de Mercadorias \& Futuros.

in the foreign currency with correspondent banks abroad. The transfer of funds takes place within the same settlement window.

- In April 2003, HKICL introduced EUR CHATS for the settlement of euro payments. The system is similar to USD CHATS, with the settlement bank being Standard Chartered in London. A novel feature of the combined CHATS systems is that it allows for PvP settlement of USD-HKD and EUR-HKD as well as USD-EUR foreign exchange trades. In the Table 1 taxonomy, this system enables the settlement of multiple currencies for domestic system participants.

- In August 2003, Clearing Corporation of India, Ltd. (CCIL), introduced a system that clears and settles interbank FX trades, including Indian rupee (INR) and USD. CCIL is a third-party member of CLS Bank and currently uses ABN AMRO in New York as its settlement bank. ${ }^{13}$

Many of these systems can be understood as substitutes for traditional correspondent banking services. The systems offer a customized local service in the native language, operating hours that accommodate their customers' needs, and potentially better risk management through the use of more formal rules and procedures.

We refer to systems that settle a foreign currency for domestic, remote, or cross-border participants as offshore systems. Offshore systems settling USD have experienced strong growth rates, albeit from a low initial level (Chart 2). All three USD offshore systems settled about USD 1,500 billion

${ }^{13}$ Other offshore USD systems in operation are the Moscow Interbank Currency Exchange in Russia and the Philippine Domestic Dollar Transfer System. 
Chart 3

Annual Value Settled by Euro Offshore Systems, 1999-2006

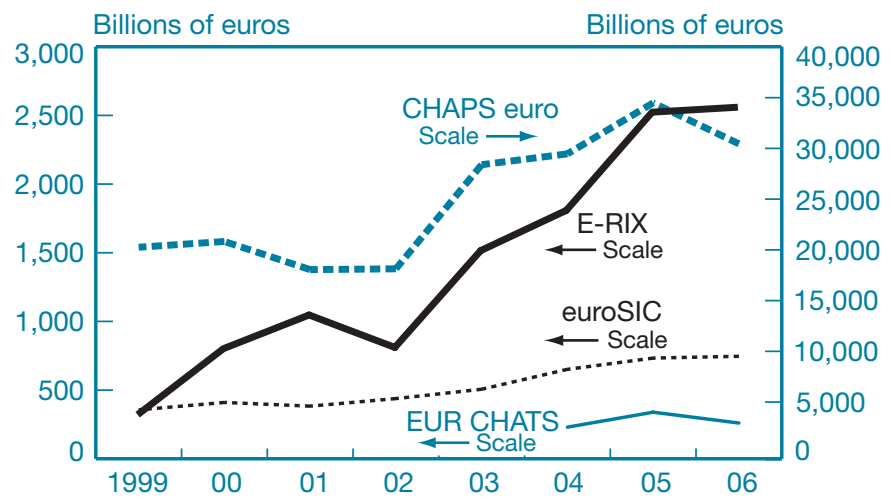

Sources: Bank for International Settlements; authors' calculations.

in 2006. In euro offshore systems, growth has been more modest-especially considering the fact that the fastestgrowing systems, CHAPS Euro and E-RIX, have been discontinued (Chart 3). All of the offshore systems (excluding CHAPS Euro), however, are still of smaller orders of magnitude than the smallest domestic LVPS in the CPSS countries.

\section{Trend 4: The Rise of Continuous Linked Settlement Bank}

Traditionally, foreign exchange settlement was carried out bilaterally between trade parties through the use of correspondent banking arrangements. ${ }^{14}$ Such arrangements lead to exposures because there is no direct link between the payment of the two currency legs; thus, there is a risk (called Herstatt risk) of paying the currency sold but not receiving the currency bought. This risk, combined with the vast size of daily FX trading and the global interdependence of FX markets and payments systems, raised concerns among central banks.

In March 1996, the BIS issued a report titled "Settlement Risk in Foreign Exchange Transactions." The report analyzed in particular the risks associated with FX settlement operations and outlined a strategy for reducing them. Based on this report, the G-10 central banks endorsed a three-track strategy to reduce these risks. First, individual banks were requested to

\footnotetext{
${ }^{14}$ Correspondent banking is an arrangement under which one bank (correspondent) holds deposits owned by other banks (respondents) and provides payment and other services to those respondent banks (Bank for International Settlements 2003). Correspondent relationships are sometimes formalized; the benefit is that parties to a trade do not have to know each other because the system's rules replace individual agreements between them.
}

take measures to control their FX settlement exposures by improving their practices for measuring and managing exposures. Second, industry groups were encouraged to develop well-constructed multicurrency services that would contribute to the risk-reduction efforts of individual banks. Third, central banks committed themselves to encouraging and fostering private sector development in this field. They also agreed to improve national payments systems to facilitate private sector risk-reduction efforts.

Since 1996, there has been considerable progress on all three tracks of the strategy. In particular, the launch of CLS Bank in September 2002 was a significant move forward by the industry to reduce foreign exchange settlement risk. CLS Bank operates a multicurrency system that settles payments for participants located on every continent. As transactions are settled on a PvP basis, Herstatt risk associated with these trades is virtually eliminated. CLS Bank is a special-purpose U.S. bank supervised by the Federal Reserve and under the cooperative oversight of the central banks of the fifteen currencies included in the system. It has grown extremely fast and is on par with Fedwire and TARGET in terms of value settled (Chart 4).

On March 19, 2008, CLS Bank settled a record 1,113,464 payment instructions with a gross value of USD 10.3 trillion. CLS Bank has grown steadily since its inception as a result of increasing FX volumes, new currencies, and greater market penetration. It now settles more than USD 200 trillion per quarter and had surpassed both Fedwire and TARGET in terms of value settled in the second half of 2005. Chart 4 also displays the euro and USD values settled in CLS Bank. Whereas TARGET

Chart 4

Value Settled in CLS Bank Compared with Fedwire and TARGET, 2003-06

Three-Month Moving Average

Trillions of U.S. dollars

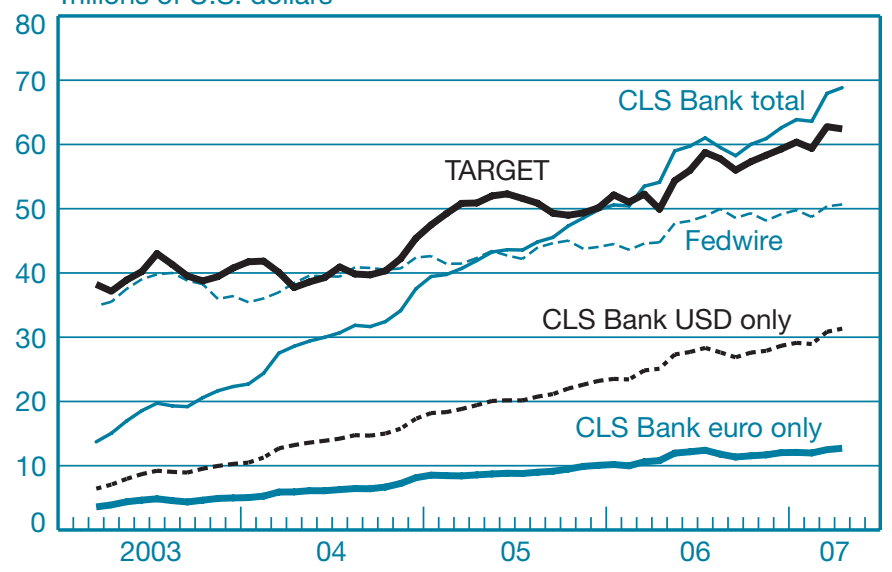

Sources: Bank for International Settlements; authors' calculations. 
TABLE 2

Total Foreign Exchange Obligations Settled, by Method, 1997 and 2006

\begin{tabular}{lccc} 
& & \multicolumn{2}{c}{ Percentage of Total Value } \\
\cline { 3 - 4 } Settlement Method & $\begin{array}{l}\text { Value (Trillions } \\
\text { of U.S. Dollars) }\end{array}$ & 1997 & 2006 \\
\hline $\begin{array}{l}\text { CLS Bank (PvP) } \\
\begin{array}{l}\text { Traditional correspondent } \\
\text { banking }\end{array}\end{array}$ & 2,091 & 0 & 55 \\
$\begin{array}{l}\text { Bilateral netting } \\
\begin{array}{l}\text { Other } \\
\text { Total }\end{array}\end{array}$ & 1,224 & 85 & 32 \\
& 304 & 15 & 8 \\
& 203 & 100 & 5
\end{tabular}

Source: Bank for International Settlements (2007b).

Note: PvP is payment-versus-payment.

settled five times the euro value settled in CLS Bank, Fedwire settled about 1.7 times the USD value settled in CLS Bank.

Ten years after the strategy was launched, the Committee on Payment and Settlement Systems conducted a survey to assess the extent to which systemic risk had been reduced (Bank for International Settlements 2007b). The survey included 109 institutions that represent 80 percent of the FX market in the fifteen currency areas. ${ }^{15}$

The institutions reported average daily gross values of FX settlement obligations totaling USD 3.8 trillion (Table 2). Of these obligations, 32 percent (USD 1.2 trillion) were settled by traditional correspondent banking arrangements and are still subject to settlement risk. Nonetheless, this is a significant improvement from the time of the 1997 survey, when an estimated 85 percent of the obligations were settled by this method. The major reason for the decline in FX obligations subject to settlement risk is the increasing use of CLS Bank. In 2006, CLS Bank settled 55 percent (USD 2.1 trillion) of the total FX settlement obligations of the surveyed institutions. Furthermore, 8 percent of FX obligations were settled by bilateral netting. ${ }^{16}$ Other settlement methods, such as the PvP arrangement available in Hong Kong's USD CHATS and EUR CHATS systems or on-us settlement, ${ }^{17}$ accounted for the remaining 5 percent of obligations.

\footnotetext{
${ }^{15}$ The survey updated and extended previous CPSS surveys conducted in 1996 (Bank for International Settlements 1996) and 1997 (Bank for International Settlements 1998).

${ }^{16}$ Provided it is conducted under legally robust arrangements, bilateral netting can also be a safe and efficient method for reducing settlement exposures (Bank for International Settlements 2007b).

${ }^{17}$ In on-us settlement, both legs of an FX trade are settled on the books of a single institution (Bank for International Settlements 2007b).
}

Even though major progress has been made in reducing aggregate foreign exchange settlement exposures, the size and duration of the exposures still settled by traditional correspondent banking are significant. In its assessment, the CPSS recommends actions to address the remaining exposures that may continue to present systemic risk.

\section{Trend 5: Increasing Settlement VAlues AND VOLUMES}

Available data suggest that the values transferred over largevalue payments systems in Committee on Payment and Settlement Systems countries grew substantially during the 1980s and 1990s. Table 3 summarizes the annual growth in nominal payment values in local currencies since 1985 for four systems for which such long-ranging data are available. In the United States, the number of transfers originated over both Fedwire and CHIPS grew by 6 percent per year on average from 1985 to 2000. In terms of value, turnover increased by an average of 9 percent per year. Since 2000, both systems have experienced a slight slowdown in growth, with volumes increasing by 4 percent and 5 percent and values by 7 percent and 9 percent, respectively.

TABle 3

Annual Turnover Growth for Selected Large-Value Payments Systems, Nominal Values

Percent

\begin{tabular}{ccccc} 
& \multicolumn{5}{c}{ Average Annual Growth } \\
\cline { 2 - 5 } & CHAPS & Fedwire & CHIPS & SIC \\
\cline { 2 - 5 } & \multicolumn{5}{c}{ Volume } \\
\cline { 2 - 5 } $1985-2006$ & 14 & 6 & 6 & 11 \\
$1985-2000$ & 16 & 6 & 6 & 9 \\
$2000-06$ & 7 & 4 & 5 & 13 \\
& & & & \\
& & & & \\
$1985-2006$ & 17 & 8 & 8 & 2 \\
$1985-2000$ & 22 & 9 & 9 & 0 \\
$2000-06$ & 3 & 7 & 5 & 4
\end{tabular}

Sources: CHIPS; Federal Reserve Bank of New York; Bank of England; Swiss National Bank; authors' calculations.

Notes: Systems are described in Appendix A. For SIC, the growth rates are calculated using data from 1989 to 2006. 
Chart 5

Time Series of Value of Transfers in CHIPS and Fedwire since 1985

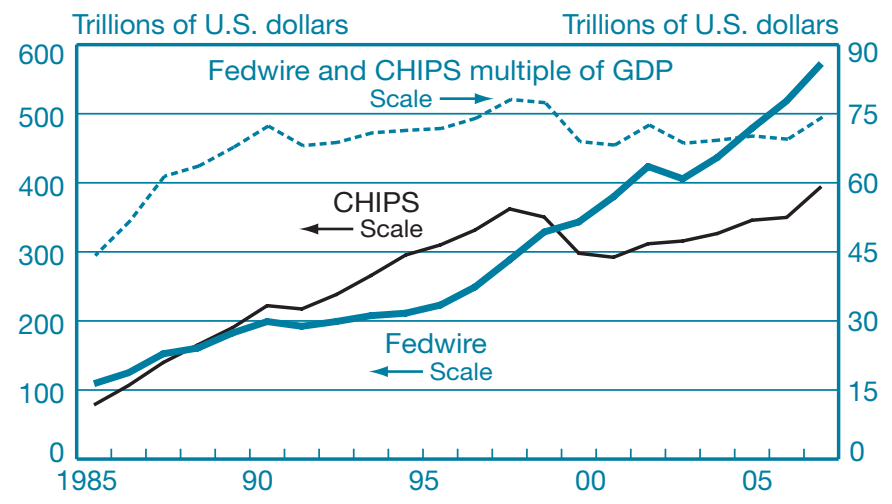

Sources: CHIPS; Federal Reserve Bank of New York; authors calculations.

In the United Kingdom, CHAPS saw double-digit turnover growth in terms of volumes and values from 1985 to 2000. However, since the turn of the century, growth has decreased. In Switzerland, the picture is a bit different, as volumes have been growing faster since 2000. If growth is measured in Swiss francs, though, turnover since 2000 has been almost flat, at around CHF 45 trillion.

Chart 5 shows the annual turnover for Fedwire and CHIPS since 1985. Fedwire turnover increased from around USD 100 trillion in 1985 to more than USD 570 trillion in 2006. Values settled in CHIPS were smaller than those settled in Fedwire from 1985 to 1988 . However, between 1988 and 1998, settlement values in CHIPS surpassed those in Fedwire. After settlement values in CHIPS dipped in the late 1990s, ${ }^{18}$ they have steadily risen again and amounted to USD 395 trillion in 2006.

A major determinant of the value of interbank payments is general economic activity. Since 1990, the combined settlement value on Fedwire and CHIPS has kept pace with economic activity, at around seventy times GDP (Chart 5, right axis). However, from 1985 to 1990, combined turnover on the two systems rose from forty-five times GDP to almost seventy-five times GDP. Likely explanations are technological development, deregulation of financial markets, and innovation in financial instruments. ${ }^{19}$

\footnotetext{
${ }^{18}$ This point is addressed in more detail in our Trend 9 discussion.

${ }^{19}$ Similar developments also took place outside the United States. Annual turnover in the United Kingdom's CHAPS system rose from seven times GDP in its first full year of operation, 1985, to more than fifty times GDP at the turn of the century. In Switzerland, annual turnover reached 120 times GDP in 1997; it has since fallen to around 90 times GDP in 2006, the same level as in 1989.
}

Chart 6 shows the relative importance of the CPSS countries' interbank payments systems in terms of value settled. Currently, the three largest systems represent more than 75 percent of value transferred. The six largest systems represent almost 95 percent. The largest individual LVPS is TARGET, with an annual settlement value of EUR 489 trillion (USD 607 trillion). The two U.S. systems, Fedwire and CHIPS, respectively rank second and third. However, their combined share of turnover, 45 percent, exceeds the share of combined turnover of the euro payments systems TARGET and EURO1, 34 percent.

The number of transfers settled increased in all of the CPSS countries' payments systems (Chart 7). The Swiss SIC system stands out, with more than 250 million payments settled in 2005. SIC is notable because there is no separate system for settling retail payments in the Swiss payment infrastructure. Thus, retail as well as wholesale payments are settled in SIC. (The settlement of low-value payments in LVPSs

Chart 6

Percentage of Transfer Value in CPSS Countries' Large-Value Payments Systems, 2005

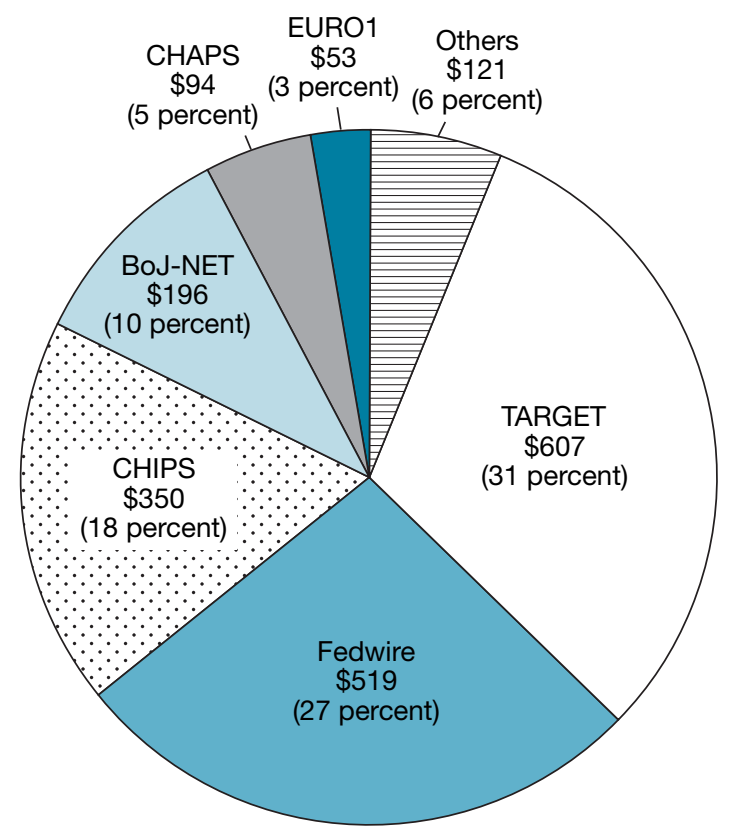

Sources: Bank for International Settlements; authors' calculations.

Notes: Dollar amounts are in trillions of U.S. dollars. "Others" includes SIC, LVTS, PNS, HKD CHATS, K-RIX, MEPS, and USD CHATS (in size order). Systems are described in Appendix A. CPSS is the Committee on Payment and Settlement Systems. 
Chart 7

Transactions Settled by CPSS Countries' Large-Value Payments Systems, 1999 and 2005

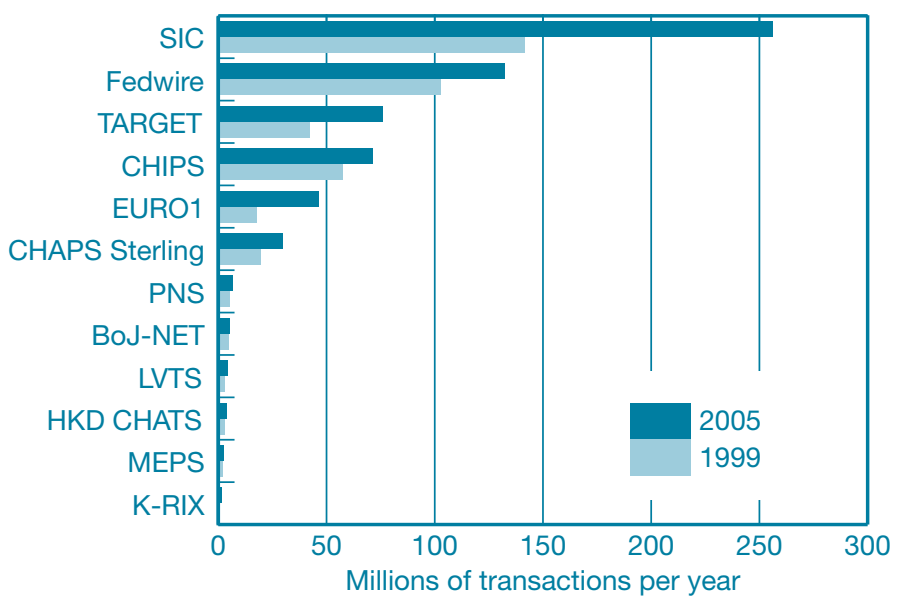

Sources: Bank for International Settlements; authors' calculations.

Notes: Systems are described in Appendix A. CPSS is the Committee on Payment and Settlement Systems.

is discussed in more detail in the next section.) Fedwire settled the second highest number of transactions, 132 million. In 2005, TARGET settled 72 million transactions and CHIPS settled 76 million.

\section{Trend 6: Shrinking Average Payment Sizes}

Payments processed through large-value payments systems come in many sizes. The maximum value of a payment allowed over Fedwire is one cent less than USD 10 billion; on occasion, payments of less than USD 1 are processed. In fact, most LVPSs process a significant amount of relatively low-value payments. As a result, the dichotomy between small-value (retail) and large-value (wholesale) payments systems is often blurred. In Fedwire and CHIPS, the median payment size is less than USD 35,000, and almost two-thirds of transfers are for amounts less than USD 100,000. Hence, both systems are important for making low-value payments. The appeal of making low-value transfers in Fedwire derives from the speed, certainty, and finality of settlement and, in some cases, from the ease of reconciliation. ${ }^{20}$ In addition, the value distribution has a fat
Chart 8

Value of Average Payment in CPSS Countries' Large-Value Payments Systems, 1999 and 2005

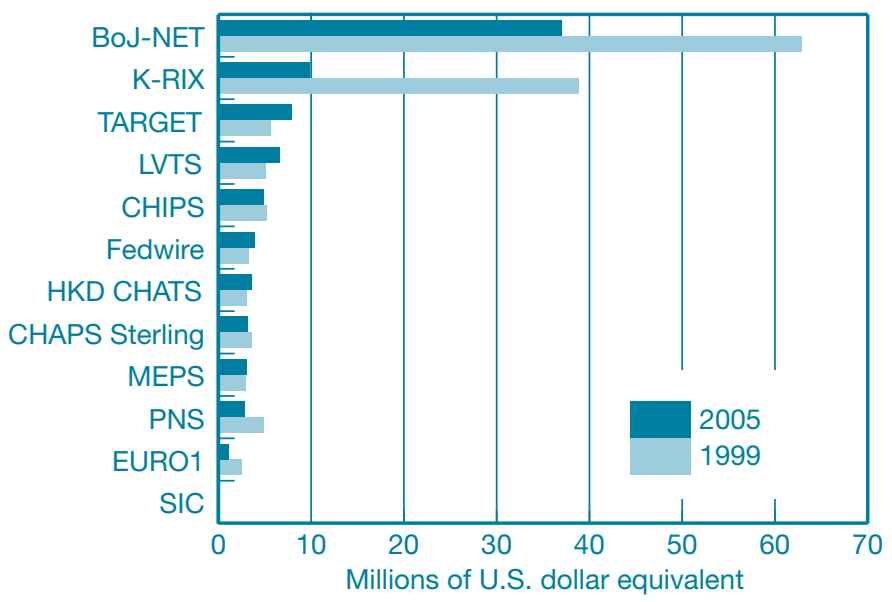

Sources: Bank for International Settlements; authors' calculations.

Notes: Systems are described in Appendix A. CPSS is the Committee on Payment and Settlement Systems.

right-hand tail. In other words, a small number of payments account for a large share of value. In Fedwire, 5 percent of the largest payments account for 95 percent of the total value.

The considerable use of low-value wire transfers is not just a U.S. phenomenon. The distribution of payments handled in the Canadian LVTS is similar to that of the U.S system. The mean value is CDN 8 million (USD 6.6 million), while the median value is about CDN 50,000 (USD 41,300). In the United Kingdom, the mean value of wire transfers processed by CHAPS Sterling is GBP 1.9 million (USD 3.45 million), and the median value is estimated to be approximately GBP 25,000 (USD 45,500). The bulk of payments in Switzerland's SIC system is less than CHF 5,000 (USD 4,000).

Looking across large-value payments systems in CPSS countries, we observe a remarkable dispersion in average payment value (Chart 8). In BoJ-NET, the average payment was in excess of 3.8 billion JPY (USD 35 million) in 2005-the highest among the LVPSs surveyed and three times larger than the second-ranking K-RIX system of the Swedish Riksbank. Nonetheless, this is a significant drop from 1999, when the

${ }^{20}$ See Federal Reserve Board, "A Summary of the Roundtable Discussion on the Role of Wire Transfers in Making Low-Value Payments," May 16, 2006 (available at <http://www.federalreserve.gov/paymentsystems/lowvaluepay/ default.htm $>$ ). 
Chart 9

Inflation-Adjusted Change in Average

Payment Size for CPSS Countries'

Large-Value Payments Systems,

1999-2005

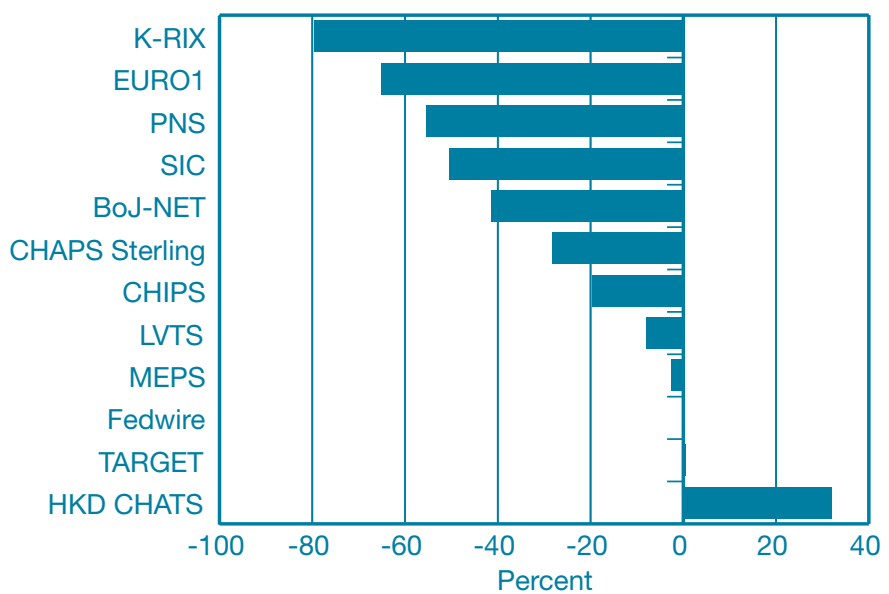

Sources: Bank for International Settlements; authors' calculations.

Notes: Systems are described in Appendix A. CPSS is the Committee on Payment and Settlement Systems.

average payment value was more than JPY 6,941 million (USD 63 million). The drop is attributable to the change from a deferred net settlement to a real-time gross settlement system in 2001. An upper limit of JPY 5 billion per payment was set to allow for smoother settlement in the new RTGS system.

TARGET is ranked third and followed by the North American systems. At the other end of the spectrum is the SIC system, with SFR 160,000 (USD 130,000), along with the euro systems PNS (USD 2.9 million) and EURO1 (USD 1.2 million).

Adjusting for inflation, Chart 9 shows that the average payment size has fallen for most systems from 1999 to 2005. For five of the twelve systems, it fell more than 40 percent. For Fedwire and TARGET, the average size has remained unchanged. The only increase in payment size adjusted for inflation occurred in the HKD CHATS system; it is to a large extent attributable to the period of deflation that Hong Kong experienced between 1999 and $2004 .^{21}$

\footnotetext{
${ }^{21}$ The consumer price index in Hong Kong fell 12 percent between 1999 and 2004.
}

\section{Trend 7: Falling Numbers of System Participants}

One of the most pervasive trends in international banking is consolidation. All else equal, larger banks imply fewer participants in LVPSs. In addition, an increasing focus on costs has made banks more selective in terms of the systems in which they participate. It is no longer considered "a must" for many foreign banks to clear their USD payments themselves as it was in the 1980s and 1990s. However, technological advances have made it possible to participate in more systems in new ways, as we describe in the emergence of cross-border and offshore systems (Trend 3).

According to figures reported to the Bank for International Settlements as part of its "Red Book" statistics, Fedwire had 10,000 participants in the late 1990s and 6,819 participants in 2005. Despite this decrease, Fedwire is still by far the largest LVPS in the CPSS group. The second largest system is TARGET, with 2,628 participants. With only twelve direct participants, the Canadian LVTS is the smallest system in the CPSS group (Table 4).

Most LVPSs in the CPSS group saw participation decline from 1999 to 2005 (Table 4). However, there was a substantial

TABLE 4

Ranking of CPSS Countries' Large-Value Payments Systems by Number of Participants, 1999 and 2005

\begin{tabular}{lccccc} 
& & $\begin{array}{c}\text { Total } \\
\text { Participants, }\end{array}$ & \multicolumn{3}{c}{$\begin{array}{c}\text { Total } \\
\text { Participants, }\end{array}$} \\
System & Ranking & 1999 & Ranking & 2005 & $\begin{array}{c}\text { Percentage } \\
\text { Change }\end{array}$ \\
\hline Fedwire & 1 & 9,994 & 1 & 6,819 & -32 \\
TARGET & 2 & 5,144 & 2 & 2,628 & -49 \\
BoJ-NET & 3 & 409 & 3 & 357 & -13 \\
SIC & 5 & 291 & 4 & 325 & 12 \\
CHAPS & 4 & 404 & 5 & 241 & -40 \\
HKD CHATS & 6 & 151 & 6 & 129 & -15 \\
MEPS & 7 & 136 & 7 & 111 & -18 \\
EURO1 & 9 & 72 & 8 & 75 & 4 \\
CHIPS & 8 & 77 & 9 & 48 & -38 \\
PNS & 10 & 25 & 10 & 45 & 80 \\
K-RIX & 11 & 23 & 11 & 21 & -9 \\
LVTS & 12 & 14 & 12 & 15 & 7
\end{tabular}

Sources: Bank for International Settlements; authors' calculations.

Notes: Systems are described in Appendix A. CPSS is the Committee on Payment and Settlement Systems. 
increase in the number of participants in SIC and, even more so, in PNS. ${ }^{22}$ SIC's growth in participation is attributable to its opening to "remote membership" in 1998 (see our Trend 3 discussion). The number of remote participants in SIC has since increased, whereas the number of Swiss participants has remained largely unchanged.

\section{Trend 8: Extended Operating Hours}

A direct effect of the globalization of financial markets is the extension of operating hours in large-value payments systems. Between 1997 and 2005, there were two waves of operating hour extensions in CPSS countries' large-value payments systems. The first occurred in 1998 and 1999, when several European LVPSs changed or extended their operating hours to coincide with TARGET's business hours. The second wave coincided with the launch of CLS Bank in 2002. BoJ-NET, MEPS, and LVTS extended their operating hours to

\footnotetext{
${ }^{22}$ For PNS, the increase in participants is attributable to an increase in the number of indirect participants; by and large, it can be explained by a reclassification of their status that took place over the period.
}

synchronize with CLS Bank settlement hours during the European morning. The CLS Bank settlement process takes place during a five-hour window from 7:00 a.m. to noon

\section{A direct effect of the globalization \\ of financial markets is the extension \\ of operating hours in large-value \\ payments systems.}

(CET). Its operating hours partially overlap the operating hours of all the participating RTGS systems (Chart 10).

To meet industry requests to achieve greater overlap of U.S. wholesale payments system operating hours with those of the Asia-Pacific markets, Fedwire and CHIPS expanded their operating hours in 1997 and 2004. In both instances, the opening was moved to earlier while the closing remained unchanged.

In 2007, SIC had the longest operating hours-23 hours and 15 minutes-approaching a twenty-four-hour settlement cycle. The three North American systems-Fedwire, CHIPS,

Chart 10

Opening Hours of CLS Bank and Selected CPSS Countries’ Large-Value Payments Systems

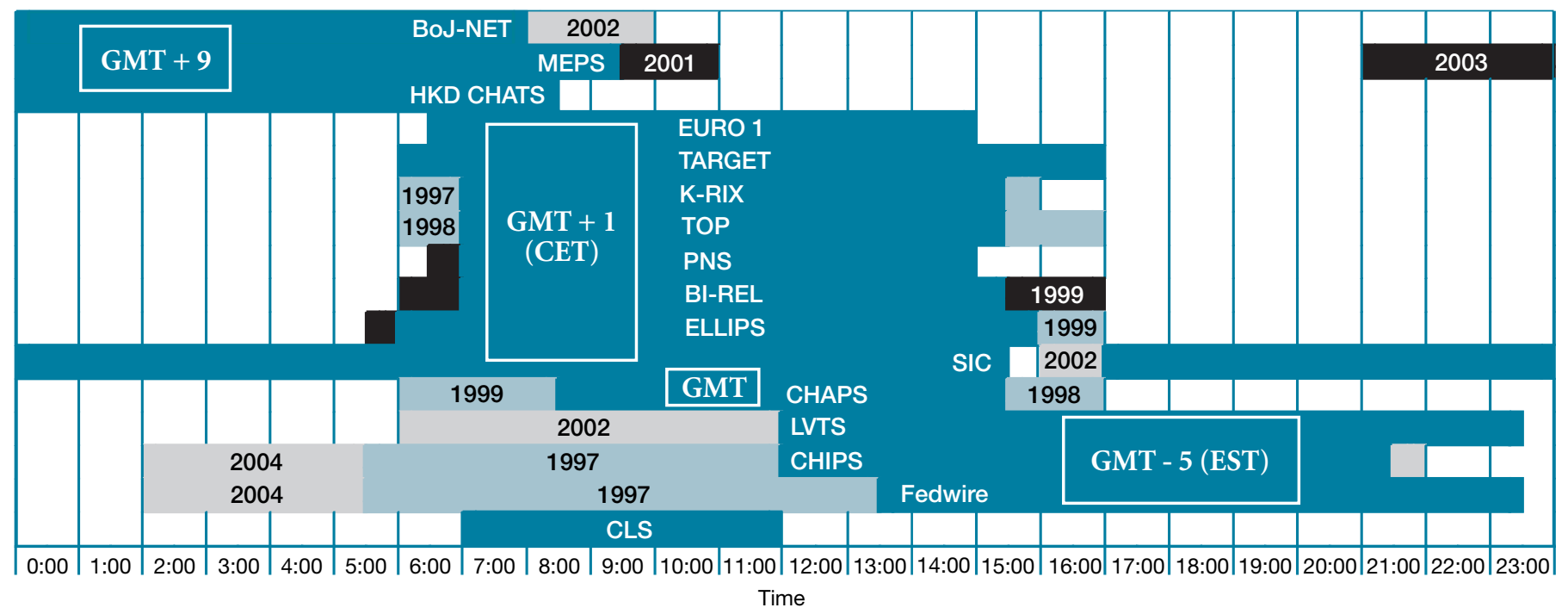

Sources: Bank for International Settlements; authors' calculations.

Notes: The blue and black shading represents the operating hours in 1996 or when the system was implemented. The full extent of all shaded areas (excluding the black areas, which represent opening hour shortenings in 1999 and before) is operating hours in 2005 . Green shading indicates extensions in 1999 and before; grey shading shows extensions after 1999. Systems are described in Appendix A. 
Chart 11

Length of Operating Hours of Selected CPSS

Countries' Large-Value Payments Systems,

1997 and 2007

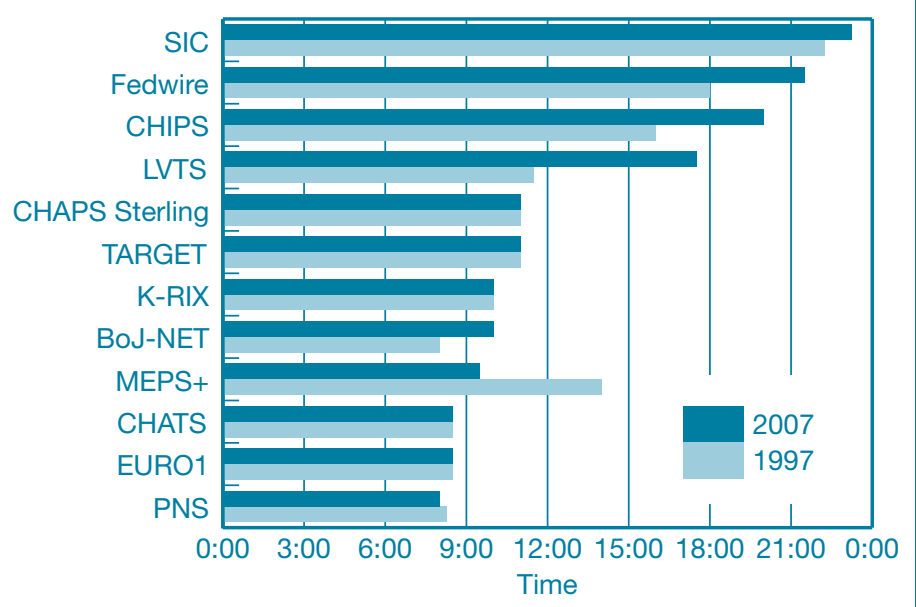

Sources: Bank for International Settlements; authors' calculations.

Notes: Systems are described in Appendix A. CPSS is the Committee on Payment and Settlement Systems.

and LVTS—followed with 21.5, 20, and 17.5 hours, respectively. At the other end of the spectrum were the European systems PNS and EURO1 and the Asian systems MEPS and HKD CHATS, with operating hours of between 8 and 9.5 hours. A reduction in operating hours occurred only in the Singaporean system MEPS and, to a lesser extent, in the French PNS system (Chart 11).

\section{Trend 9: Declining Transaction Fees}

Large-value payments systems are characterized by large economies of scale, as there are considerable fixed costs in terms of setting up and maintaining the systems. In contrast, individual payments generate diminutive costs. This creates a potential problem for efficient pricing. Standard economic theory suggests that each transaction should be priced at its marginal cost. However, marginal cost pricing implies that the fixed costs are not recovered (see Holthausen and Rochet [2006]). Central banks and system operators around the world have found different solutions to this challenge, depending on their mandate for the provision of payment services.
Most systems charge a fixed membership or admission fee and the majority charge a per-transaction fee. However, differences exist in terms of whether both the originator and the receiver are charged for a transaction. TARGET only charges the originator whereas both Fedwire and SIC levy fees on both the originator and the receiver. A simple, flat transaction fee schedule is often used, but several systems base the fee on a combination of the volume submitted by the participant, the value of the particular payment, the submission time of the payment, and the mode of delivery, such as online and offline. In addition, participants may have to pay separate communications charges, for example, to SWIFT.

In 1999, the Federal Reserve implemented a volume-based fee schedule to reflect more accurately the cost structure of Fedwire services and its demand elasticity. This type of structure remains in place today, in which offline participants are also assessed a surcharge to initiate or receive a funds

Large-value payments systems are characterized by large economies of scale, as there are considerable fixed costs in terms of setting up and maintaining the systems. In contrast, individual payments generate diminutive costs. This creates a potential problem for efficient pricing.

transfer. In Switzerland, the originator of the payment is charged differently depending both on the time when the payment is submitted and its value. The SIC pricing schedule is illustrated in Table 5. The receiver is charged a flat fee regardless of the settlement time and value. The fee structure provides an incentive for early input and settlement of payments, which in turn prevents the demand for settlement from peaking at the end of the day (see Heller, Nellen, and Sturm [2000]). For cross-border payments, TARGET has a transparent, volume-based pricing structure. Domestic payments are currently priced by each TARGET component independently.

In the second half of the 1990s, the Federal Reserve undertook a five-year project—akin to the current TARGET2 initiative-to consolidate its processing facilities. The project resulted in significant savings that were passed on to users in the form of lower fees. The average transaction fee (nominal) 
TABLE 5

Pricing Principles in Fedwire, TARGET, and SIC

\begin{tabular}{|c|c|c|c|c|c|c|c|c|}
\hline & \multirow[b]{3}{*}{ Volume-Based } & \multirow[b]{3}{*}{ Value-Based } & \multirow[b]{3}{*}{ Time of Day } & \multirow[b]{3}{*}{$\begin{array}{l}\text { Mode of } \\
\text { Delivery }\end{array}$} & \multicolumn{4}{|c|}{ Transaction Fee (U.S. Dollar Equivalent) } \\
\hline & & & & & \multicolumn{2}{|c|}{ Lowest } & \multicolumn{2}{|c|}{ Highest } \\
\hline & & & & & Sender & Total & Sender & Total \\
\hline Fedwire & $\mathrm{Y}$ & $\mathrm{N}$ & $\mathrm{N}$ & $\mathrm{Y}$ & 0.1 & 0.2 & 0.3 & 0.6 \\
\hline TARGET & Y & $\mathrm{N}$ & $\mathrm{N}$ & $\mathrm{N}$ & 1.1 & 1.1 & 2.4 & 2.4 \\
\hline SIC & $\mathrm{N}$ & $\mathrm{Y}$ & $\mathrm{Y}$ & $\mathrm{N}$ & 0.01 & 0.03 & 3.7 & 3.7 \\
\hline
\end{tabular}

Sources: European Central Bank; Federal Reserve Bank of New York; Swiss National Bank.

Note: Total $=$ sender + receiver, exchange rate of May 25, 2007.

in Fedwire dropped from USD 0.50 in 1996 to less than USD 0.16 in 2006-a reduction of 68 percent (Chart 12). SIC participants have seen a similar drop, as the average transaction fee fell from 17 centimes in 1999 to 7 centimes in 2005-a reduction of 60 percent. TARGET transaction fees have been fixed at the same nominal rates since 1999.

Pricing in LVPSs is important not only from a revenue and cost perspective but also from a competitive perspective when private and public systems co-exist as they do in Europe and the United States. As an example, the growth in the respective volumes of payments submitted to Fedwire and CHIPS since 1990 is illustrated in Chart 12. Both systems have more than doubled the amount of payments they process. However,

\section{Chart 12 \\ The Effect of Fedwire Price Reductions on CHIPS Volume}

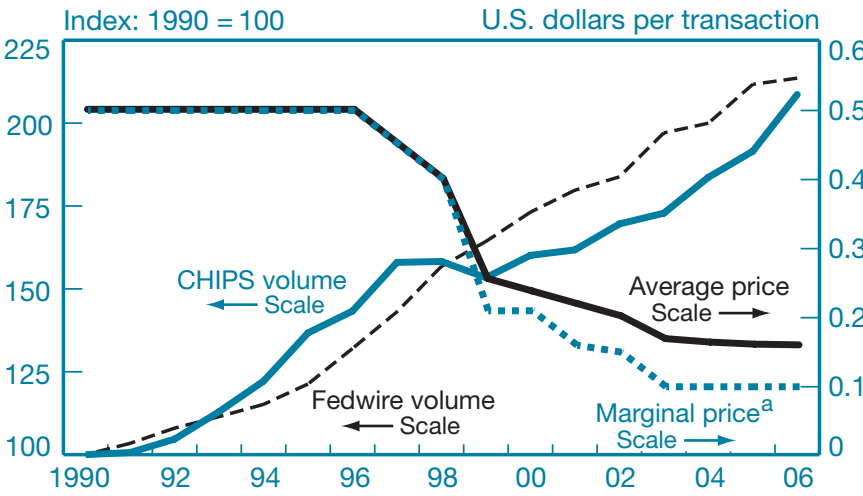

Sources: CHIPS; Federal Reserve Bank of New York; authors' calculations.

${ }^{\mathrm{a}} 80,000$ or more transactions. the trajectory of volumes processed over CHIPS declined significantly in the late 1990s and did not recover until 2001. At the same time, Fedwire was experiencing steady growth. This change coincides with the reduction in Fedwire fees and the move to volume-based pricing. Conversely, in late 2005, CHIPS announced new incentive pricing for existing and new participants. Based on one year of data, incentive pricing appears to have had some effect, as Fedwire volume grew by only 1 percent-the lowest rate in twenty years-while CHIPS volume grew by 9 percent.

\section{Trend 10: Adoption of Common Standards For Large-Value Payments Systems}

In 1980, the governors of the central banks of the G-10 countries established the Group of Experts on Payment Systems. One of the Group's first projects was to conduct a detailed review of payments system developments in the G-10 countries. It was published by the BIS in 1985 in the first of a series that has become known as the "Red Book." The Group also analyzed interbank netting schemes in the Angell Report ("Report on Netting Schemes") and in the Lamfalussy Report ("Report of the Committee on Interbank Netting Schemes of the Central Banks of the Group of Ten Countries"), published by the BIS in 1989 and 1990, respectively. In 1990, the G-10 governors established the Committee on Payment and Settlement Systems to assume and extend the activities of the Group of Experts on Payment Systems. The CPSS was set up as one of the BIS' permanent central bank committees reporting to the $\mathrm{G}-10$ governors. 
The CPSS has focused on disseminating information on payments system design and has been defining payment norms and best practices for the central bank community. In 1997, the CPSS published a report on real-time gross settlement systems and in 2005 a report on new developments in large-value

The standards published by the CPSS [Committee on Payment and Settlement Systems] provide the main principles for the design and operation of payments and settlement systems.

payments systems that focused on changes since the RTGS report. Furthermore, in January 2001, the CPSS published the "Core Principles for Systemically Important Payment Systems." The document was developed to serve as guidelines for promoting safety and efficiency in the design and operation of systemically important payments systems (SIPSs). ${ }^{23}$

The standards published by the CPSS provide the main principles for the design and operation of payments and settlement systems. They are currently being used as a reference by central banks and international organizations in their efforts to improve the safety and efficiency of payments systems worldwide. They are part of a set of key standards that the international community considers essential to strengthening and preserving financial stability. As such, these standards are used by the joint IMF and World Bank Financial Sector Assessment Program (FSAP) and the Reports on the Observance of Standards and Codes.

A growing number of LVPSs around the world have been assessed according to the Core Principles. This has occurred either as a self-assessment by the system operator, the central bank, or as part of an FSAP review. In some cases, systems have even been self-assessed and assessed by the IMF and the World Bank. Some central banks, such as the Bank of England and the Swedish Riksbank, use the Core Principles for annual assessments of their SIPSs as part of their payments system oversight.

The first country to assess its payments system according to the Core Principles was Canada. In late 1999, Canada participated in an FSAP pilot that included an assessment of the Canadian payments system, LVTS, using a draft version of the Core Principles. The payments systems in Cameroon and

\footnotetext{
${ }^{23}$ A payments system is systemically important when, if the system were insufficiently protected against risk, disruption within it could trigger or transmit further disruptions among participants or systemic disruptions in the financial area more widely (Bank for International Settlements 2003).
}

Estonia were assessed in 2000. In January 2001, the Governing Council of the European Central Bank adopted the Core Principles as the minimum standards for the Eurosystem's common oversight policy on systemically important payments systems. As a consequence, the Governing Council decided that all nineteen SIPSs in the euro area would be assessed against the Core Principles in mid-2003.

Exhibit 2 on the next page displays the countries that have applied the Core Principles to assess their LVPSs. At the end of 2006, fifty-nine countries had done so-up from twenty-two at the end of 2002. Of the fifty-nine countries, twelve had been both self-assessed and under the scrutiny of the IMF and World Bank. In addition, payments systems in another forty-two countries had been assessed as part of an FSAP review, while five had conducted self-assessments. The United States belongs to the latter group.

According to the assessments, practically all SIPSs in developed countries meet the standards and codes in the Core Principles. This is also true for payments systems in many emerging economies. Private sector payments systems in major currencies also comply with the Core Principles; notable examples are CHIPS and EURO1.

\section{Future Developments}

This article describes ten long-range trends in the settlement of large-value payments. The questions worth considering are how these trends will evolve and what new developments can be foreseen. We offer some thoughts on these questions.

Currently, the diffusion of RTGS is well under way. RTGS and net settlement systems each have characteristics that make them desirable, thus the hybridization of RTGS is likely to continue as long as liquidity is costly. Many central banks require collateral for intraday credit. With the ongoing development of financial markets, collateral is likely to find new, more profitable uses than payment settlement. This will likely drive the cost of liquidity up and, as a consequence, increase the demand for liquidity saving that netting and offsetting in conjunction with RTGS can offer. The trend toward greater hybridization of systems is therefore likely to continue.

The introduction of cross-border systems has been associated with unique events linked to the introduction of the euro and the establishment of CLS Bank. Cross-border systems are likely to remain rare in the future. However, remote participation may become more prevalent.

Offshore systems that settle a foreign currency are presently small and serve niche markets—-mainly a local FX market or 


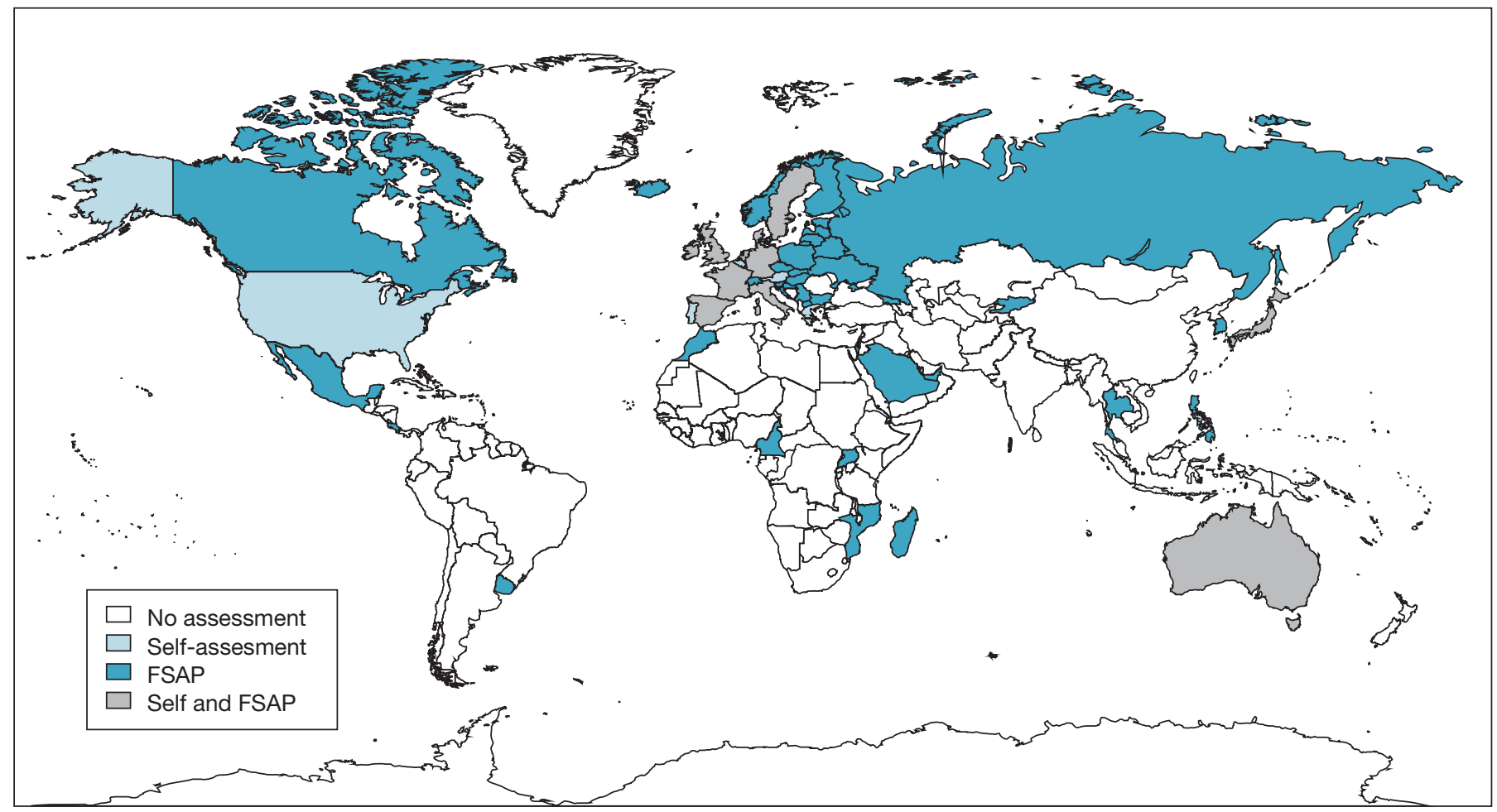

Sources: International Monetary Fund (IMF); websites of countries' central banks.

Note: FSAP is the joint IMF-World Bank Financial Sector Assessment Program.

the needs of banks in the area and time zone to settle payments in a foreign currency among each other. Such demands may arise in the context of the establishment of new financial centers, for instance, in the Middle East or China, where the People's Bank of China is developing a USD clearing system. Most existing or planned offshore systems are limited to a single country. With improvements in information and communications technologies, the fixed cost of setting up such systems is being reduced. As a consequence, we may see more offshore systems emerge, but they are likely to remain niche players, much like the existing ones are.

CLS Bank settlements have grown rapidly and are likely to continue to do so. Currently, CLS Bank captures around 50 percent of all FX trades and is pursuing the settlement of other types of transactions. As most of its costs stem from fixed investments, CLS Bank has incentives to continue fostering growth in settlement volumes.

Settlement values are likely to continue growing at the pace of GDP in the long run, and be cyclical to financial market activity in the short run-as they have done over the past ten years. The rapid growth in values attributable to financial deregulation and innovation in the 1980s and early 1990s has largely been absorbed.

The average real value of payments processed in LVPSs has declined. As transaction prices seem to be declining too, it can be expected that the benefits of real-time settlement will outweigh the costs for a wider variety of smaller financial transactions. Thus, we expect that the average value of largevalue payments will continue to fall.

Consolidation in financial services is continuing. Especially in Europe, the process of cross-border mergers has not yet taken off. In addition, the introduction of TARGET2 and the consolidation of all the EU RTGS systems into a single entity will substantially reduce the number of LVPS participants, as banks operating in several EU countries will be better positioned to manage their payments centrally.

One reason for the emergence of offshore systems is that the operating hours of domestic LVPSs do not coincide with the business hours of LVPSs in other countries. Often, the operating hours of euro or U.S. dollar LVPSs do not sufficiently overlap those of Asian financial centers. Fedwire and CHIPS have reacted to this disparity by extending their operating 
hours. The European systems have had less of a need to do so because their operating hours already overlap those of Asian financial centers by a few hours. The overlap with current operating hours, however, is now wider for the U.S. dollar than for the euro-in spite of the more advantageous time differences in Europe.

Evidence from systems for which price data are available suggests that the cost of payments in LVPSs has declined rapidly. The underlying reasons are associated with regulatory changes, lower costs of information and communications technology, and perhaps competition between the public and private systems that operate side by side in some countries. These reasons are not likely to change, and the cost of making payments is likely to continue to fall.

The final trend we discussed was the standardization of large-value payments systems through the use of common standards. The "Core Principles for Systemically Important Payment Systems" is already widely accepted and will continue to be applied around the world. 


\section{Appendix A: Large-Value Payments Systems in CPSS Member Countries}

\begin{tabular}{|c|c|c|c|c|c|}
\hline Country & System Name & Abbreviation & $\begin{array}{c}\text { Year of } \\
\text { Implementation }\end{array}$ & $\begin{array}{c}\text { Annual Number } \\
\text { of Transactions } \\
\text { (2005, in Thousands) }\end{array}$ & $\begin{array}{l}\text { Annual Value } \\
\text { of Transactions } \\
\text { (2005, in Billions } \\
\text { of U.S. Dollars) }\end{array}$ \\
\hline Belgium & $\begin{array}{l}\text { Electronic Large-Value Interbank } \\
\text { Payments System }\end{array}$ & ELLIPS $^{\mathrm{a}}$ & 1996 & 1,800 & 21,448 \\
\hline Canada & Large-Value Transfer System & LVTS & 1999 & 4,600 & 30,321 \\
\hline France & Transferts Banque de France & $\mathrm{TBF}^{\mathrm{a}}$ & 1997 & 4,300 & 151,425 \\
\hline France & Paris Net Settlement & PNS & 1999 & 6,800 & 19,432 \\
\hline Germany & RTGSplus & RTGSplus $^{\mathrm{a}}$ & 2001 & 35,800 & 172,023 \\
\hline Hong Kong & $\begin{array}{l}\text { HK Dollar Clearing House Automated } \\
\text { Transfer System }\end{array}$ & HKD CHATS & 1996 & 4,100 & 14,936 \\
\hline Hong Kong & $\begin{array}{l}\text { U.S. Dollar Clearing House Automated } \\
\text { Transfer System }\end{array}$ & USD CHATS & 2000 & 1,500 & 1,588 \\
\hline Hong Kong & $\begin{array}{l}\text { Euro Clearing House Automated } \\
\text { Transfer System }\end{array}$ & Euro CHATS & 2003 & 1,000 & 422 \\
\hline Italy & BI-REL & BI-REL1 & 1997 & 10,400 & 40,840 \\
\hline Japan & BoJ-NET Funds Transfer System & BoJ-NET & 1988 & 5,300 & 196,452 \\
\hline Netherlands & TOP & $\mathrm{TOP}^{\mathrm{a}}$ & 1997 & 4,700 & 38,126 \\
\hline Singapore & $\begin{array}{l}\text { Monetary Authority of Singapore (MAS) } \\
\text { Electronic Payments System }\end{array}$ & MEPS & 1998 & 2,500 & 7,564 \\
\hline Sweden & K-RIX & K-RIX & 1990 & 1,500 & 14,867 \\
\hline Sweden & E-RIX & E-RIX & 1999 & 1,000 & 279 \\
\hline Switzerland & Swiss Interbank Clearing & SIC & 1987 & 256,400 & 32,956 \\
\hline Switzerland & EuroSIC & EuroSIC & 1999 & 9,130 & 630 \\
\hline United Kingdom & CHAPS Sterling & CHAPS Sterling & 1984 & 29,600 & 94,299 \\
\hline United Kingdom & CHAPS Euro & CHAPS EURO1 & 1999 & 5,100 & 66,859 \\
\hline United States & Fedwire Funds Service & Fedwire & 1918 & 123,400 & 518,547 \\
\hline United States & Clearing House Interbank Payments System & CHIPS & 1970 & 71,500 & 349,871 \\
\hline European Union & $\begin{array}{l}\text { Trans-European Automated Real-time } \\
\text { Gross settlement Express Transfer system }\end{array}$ & TARGET & 1999 & 76,200 & 607,254 \\
\hline European Union & EURO1 & EURO1 & 1999 & 46,400 & 53,334 \\
\hline European Union & ECB Payment Mechanism & $\mathrm{EPM}^{\mathrm{a}}$ & 1999 & 41 & 5 \\
\hline International & Continuous Linked Settlement Bank & CLS Bank ${ }^{\mathrm{b}}$ & 2002 & 47,900 & 785,300 \\
\hline
\end{tabular}

Notes: In this article, we analyze the European TARGET system but do not consider its components (ELLIPS, TBF, RTGSplus, BI-REL, and TOP). CPSS is Committee on Payment and Settlement Systems.

a The system is a component of TARGET, which consists of fifteen national real-time gross settlement systems and the EPM system of the European Central Bank.

${ }^{\mathrm{b}}$ CLS Bank data are based on the aggregation of both sides of a foreign exchange transaction. 
TARGET (Trans-European Automated Real-time Gross settlement Express Transfer system) is the RTGS system for the euro, owned and operated by the Eurosystem. It went live in January 1999. The system is used for the settlement of central bank operations, large-value euro interbank transfers, and other euro payments. TARGET was created by interconnecting national euro RTGS systems and the European Central Bank payment mechanism.

Within TARGET, the two largest components - the German RTGSplus and the French TBF-process more than half of the values transacted. The next three largest systemsthe United Kingdom's CHAPS Euro, the Italian BI-REL, and the Dutch TOP - process another quarter of transfer values, while the remaining ten smaller components are responsible for the remaining quarter or less.

The decentralized infrastructure of TARGET is being replaced by TARGET2, which is based on a single technical platform. TARGET2 went live in November 2007. All

Eurosystem central banks and Kronos Euro will participate in the new system. E-RIX discontinued operations on January 1, 2007, and CHAPS Euro will not connect to TARGET2.
Share of Values Transferred by TARGET Components

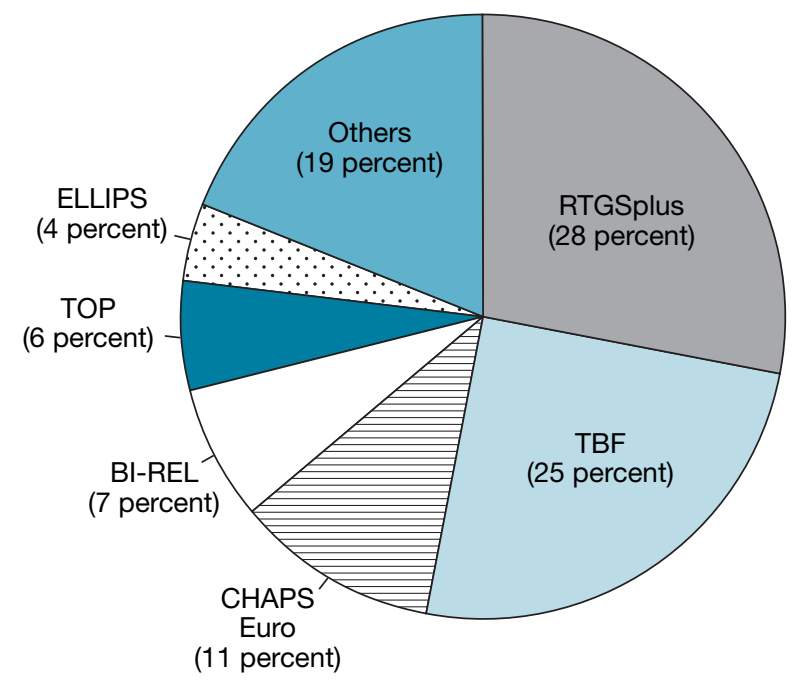

Source: European Central Bank, TARGET 2006 Annual Report. 


\section{Appendix C: Cross-Border Payments in TARGET}

In 2006, TARGET processed on average 326,000 payments a day worth about $€ 2.1$ trillion. Inter-member state or crossborder payments accounted for 23 percent of the volume and 35 percent of the value of payments transferred (see table).

Not surprisingly, the cross-border flow of payments within TARGET correlates with economic output and the size of the financial sectors across countries. The geographical network of payment flows in Europe is shown in the exhibit. Data are from 1999-2002 and hence exclude some of the newer accession countries. The size of each node is proportional to the value of intra-border or domestic payment flows, and the width of links between countries is proportional to the value of crossborder flows. The largest flows are between the three largest economies: Germany, the United Kingdom, and France. Although the United Kingdom has not yet adopted the euro, it has a prominent role in cross-border euro payment flows.

Inter- and Intra-Member State Payments in TARGET, 2006

\begin{tabular}{lccccc} 
& \multicolumn{2}{c}{ Value } & & \multicolumn{2}{c}{ Volume } \\
\cline { 2 - 3 } & $\begin{array}{c}\text { Daily } \\
\text { Average } \\
\text { (Billions } \\
\text { of Euros) }\end{array}$ & $\begin{array}{c}\text { Share } \\
\text { (Percent) }\end{array}$ & & $\begin{array}{c}\text { Daily } \\
\text { Average } \\
\text { (Thousands } \\
\text { of Payments) }\end{array}$ & $\begin{array}{c}\text { Share } \\
\text { (Percent) }\end{array}$ \\
\hline Total & 2,092 & & 326 & 23 \\
Inter-member state & 725 & 35 & & 75 & 77 \\
Intra-member state & 1,368 & 65 & & 252 &
\end{tabular}

Source: <www.ecb.int $>$.
This simply reflects the importance of London as a financial center. Interestingly, euro payment flows within the United Kingdom are minuscule in comparison. In contrast, the value of cross-border payments to and from Italy, Spain, and Portugal is less than the countries' respective shares of EU gross domestic product. The opposite is true for the Benelux countries, all of which host important financial centers (light blue lines).

\section{Geography of TARGET Cross-Border Payments}

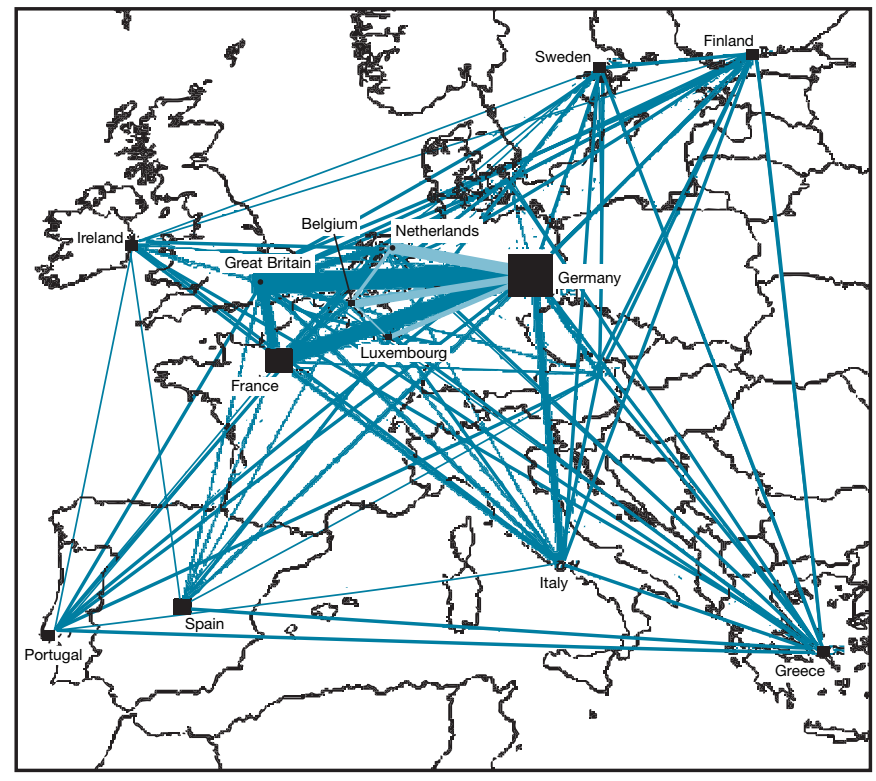

Sources: <http://www.ecb.int>; Rosati and Secola (2006). 


\section{REFERENCES}

Arjani, N., and D. McVanel. 2006. “A Primer on Canada's Large-Value Transfer System.” Bank of Canada.

Bank for International Settlements. 1996. "Settlement Risk in Foreign Exchange Transactions." Committee on Payment and Settlement Systems, Publication no 17. Basel, Switzerland.

. 1998. "Reducing Foreign Exchange Settlement Risk: A Progress Report.” Committee on Payment and Settlement Systems, Publication no 26. Basel, Switzerland.

2001. "Core Principles for Systemically Important Payment Systems." Committee on Payment and Settlement Systems, Publication no 43. Basel, Switzerland.

2003. "A Glossary of Terms Used in Payment and Settlement Systems.” Committee on Payment and Settlement Systems. March. Basel, Switzerland.

2005. "New Developments in Large-Value Payment Systems." Committee on Payment and Settlement Systems, Publication no 67. May. Basel, Switzerland.

2007a. "Statistics on Payment and Settlement Systems in Selected Countries_Figures for 2005." Committee on Payment and Settlement Systems, Publication no 78. Basel, Switzerland.

2007b. "Progress in Reducing Foreign Exchange Settlement Risk." Committee on Payment and Settlement Systems, Publication no 81. Basel, Switzerland.

Bech, M. 2007. "The Diffusion of Real-Time Gross Settlement." In S. Millard, A. Haldane, and V. Saporta, eds., The Future of Payments. Routledge International Studies in Money and Banking. London: Routledge.

Bech M., and B. Hobijn. 2007. "Technology Diffusion within Central Banking: The Case of Real-Time Gross Settlement." International Journal of Central Banking 3, no. 3 (September): 147-81.
Bech, M., and K. Soramäki. 2001. "Liquidity, Gridlocks, and Bank Failures in Large-Value Payments Systems." Central Banking Publications, E-Money and Payments System Review: 111-26.

—. 2005. "Systemic Risk in a Netting System Revisited." In H. Leinonen, ed., Liquidity, Risks, And Speed in Payment and Settlement Systems-A Simulation Approach, 275-96. Bank of Finland Studies in Economics and Finance.

Heller, D., T. Nellen, and A. Sturm. 2000. "The Swiss Interbank Clearing System.” Swiss National Bank, Payment System Subsection, June. Available at $<$ http://www.sic.ch/dl_tkicch _sicartikelsnb.pdf $>$.

Holthausen, C., and J.-C. Rochet. 2006. "Efficient Pricing of LargeValue Interbank Payment Systems.” Journal of Money, Credit, and Banking 38, no. 7 (October): 1797-818.

Humphrey, D. 1986. "Payments Finality and Risk of Settlement Failure." In A. Saunders and L. J. White, eds., Technology And the Regulation of Financial Markets: Securities, Futures, AND BANKING, 97-120. Lexington, Mass.: Heath.

Leinonen, H., and K. Soramäki. 1999. "Optimizing Liquidity Usage and Settlement Speed in Payment Systems.” Bank of Finland Discussion Paper no. 16, December.

McAndrews, J., and J. Trundle. 2001. "New Payment System Designs: Causes and Consequences." Bank of England Financial Stability Review 11, December: 127-36.

Rosati, S., and S. Secola. 2006. "Explaining Cross-Border Large-Value Payment Flows- Evidence from TARGET and EURO 1 Data." Journal of Banking and Finance 30, no. 6 (June): 1753-82.

Selgin, G. 2004. "Wholesale Payments: Questioning the MarketFailure Hypothesis." International Review of Law and ECONOMICs 24, no. 3 (September): 333-50.

The views expressed are those of the authors and do not necessarily reflect the position of the European Central Bank, the Federal Reserve Bank of New York, or the Federal Reserve System. The Federal Reserve Bank of New York provides no warranty, express or implied, as to the accuracy, timeliness, completeness, merchantability, or fitness for any particular purpose of any information contained in documents produced and provided by the Federal Reserve Bank of New York in any form or manner whatsoever. 